\title{
ON THE HORMONAL INHIBITION OF MOULTING IN DECAPOD CRUSTACEA
}

\author{
By D. B. Carlisle \\ The Plymouth Laboratory
}

Recently I have reported experiments which have led me to throw doubt on the universal applicability of the theory of the production of a moult-inhibiting hormone by the eyestalks of the decapod Crustacea (Carlisle, I953). I suggested that the eyestalk moult-inhibiting hormone might be associated with the existence of a definite moulting season. In animals which possessed such a moulting season moulting would then be inhibited outside this season, but within the season there might well be no such inhibition. The experiments reported here support a modified form of this hypothesis.

Small crabs of the species Carcinides maenas (Pennant) were used. All specimens were between 2.5 and $4 \mathrm{~cm}$. in carapace breadth. The sexes were not separated but no females were in berry. The crabs were kept individually in glass jars ( $4 \mathrm{lb}$. rock jars or Breffitt jars) of about 31 . capacity, in I 1 . of sea water. The temperature was $I 8 \cdot 4 \pm \mathrm{I} \cdot 5^{\circ} \mathrm{C}$. The animals were fed once a week on squid flesh and the water changed after feeding. A group of about 250 crabs was selected and divided at random into two groups. In group E (experimental) the left eyestalk was severed at the base and cauterized. In group $\mathrm{C}$ (control) the retinal portion of the left eyestalk was destroyed by cautery. Two days later the right eyestalks of group $\mathrm{E}$ were removed and the right eyes of group $\mathrm{C}$ seared to destroy the retinal portion. The animals which survived these operations (eighty-four of group E and eighty of group C) were then isolated in the Breffitt jars. During the next 49 days six crabs moulted in each group. On the fiftieth day the blood calcium level of the survivors which had not moulted was measured (see Table I). The death-rate had been almost identical in the two groups.

Four crabs in group $\mathrm{C}$ and five in group $\mathrm{E}$ showed signs of an approaching moult in the heightened blood calcium level. Except for these nine crabs, in which the blood calcium level was of the order of $100 \mathrm{mg} . \%$, the level ranged between 28 and $4 \mathrm{I} \mathrm{mg.} \mathrm{\%} \mathrm{in} \mathrm{both} \mathrm{groups.} \mathrm{The} \mathrm{mean} \mathrm{for} \mathrm{group} \mathrm{E}$ (excluding the five very high ones) was $33.4 \mathrm{mg} . \%$ and for group C $35.2 \mathrm{mg} . \%$. Quite clearly the two groups do not differ in this respect and neither operation precipitated moulting nor even initiated proecdysis, for then the blood calcium level would be enhanced after a full 50 days, whereas this has only happened in a few animals which doubtless had commenced proecdysis without the extraneous stimulus of the operation. 
Histological examination showed that the crabs of group $\mathrm{C}$ had intact the sinus gland and $\mathrm{X}$ organ, which were of course absent in the animals of group E. Now the moult-inhibiting hormone of crabs has been shown to emanate from the X organ-sinus gland complex (e.g. Passano, 1953). Under the experimental conditions I have employed, then, destruction of the seat of the eyestalk moult-inhibiting hormone has not precipitated moulting nor initiated proecdysis. Evidently, then, under these conditions no moult-inhibiting hormone from the eyestalk is interfering with the initiation of proecdysis.

Now according to Broekhuysen (1936) C. maenas moults seasonally. It does not moult during the months of February, March and April. This experiment started at the end of May and continued through all June and part of July.

\section{Table I. Blood Calcium Levels in the Blood of Crabs 50 Days AFTER THE BEGINNING OF THE EXPERIMENT}

\begin{tabular}{cccc}
\multicolumn{4}{c}{ (Expressed in mg./roo g.) } \\
Group E & Group C & Group E & Group C \\
$35 \cdot 0$ & $4 \mathrm{I} \cdot 6$ & $38 \cdot 7$ & $39 \cdot 6$ \\
$3 \mathrm{I} \cdot 8$ & $35 \cdot 2$ & $32 \cdot \mathrm{I}$ & $39 \cdot 2$ \\
$46 \cdot 8$ & $34 \cdot 4$ & $30 \cdot 4$ & $35 \cdot 6$ \\
$30 \cdot \mathrm{I}$ & $32 \cdot 5$ & $23 \cdot 2$ & $29 \cdot 9$ \\
$29 \cdot 2$ & $3 \mathrm{I} \cdot 8$ & $38 \cdot 4$ & $35 \cdot 9$ \\
$27 \cdot 4$ & $28 \cdot 6$ & $38 \cdot 6$ & $39 \cdot 8$ \\
$38 \cdot 5$ & $36 \cdot 8$ & & \\
$30 \cdot 3$ & $38 \cdot 2$ & $100 \cdot 7$ & $84 \cdot 3$ \\
$32 \cdot 2$ & $37 \cdot 5$ & $96 \cdot 3$ & $94 \cdot 2$ \\
$32 \cdot 7$ & $36 \cdot 5$ & $109 \cdot 8$ & $100 \cdot 3$ \\
$34 \cdot 4$ & $36 \cdot 8$ & $87 \cdot 4$ & $105 \cdot 6$ \\
$32 \cdot 5$ & $26 \cdot 4$ & $93 \cdot 7$ &
\end{tabular}

That is to say it lay wholly within the moulting season. This is the chief difference from the experiments of American workers who have experimented almost entirely on animals outside the moulting season, when they have found clear evidence of the existence of a moult-inhibiting hormone secreted by the $\mathrm{X}$ organ-sinus gland complex. This is true of Carcinides (Passano, personal communication). But within the moulting season I have found no evidence of a moult-inhibiting hormone produced by the eyestalk. That some factor is inhibiting moulting there can be no doubt, for most of the animals in both experimental groups show blood calcium levels characteristic of anecdysis. Stephens (195I) has produced evidence that a moult-inhibiting hormone is produced in the central nervous system. It is possible that this is the factor responsible for the inhibition of moulting during the moulting season in those species which during this period do not allow one metecdysis to run straight into the next proecdysis.

The conclusion seems to be that whereas outside the moulting season ecdysis may be inhibited by a hormone secreted by the $\mathrm{X}$ organ-sinus gland complex of the eyestalk, and removal of the eyestalk or of this complex leads to the initiation of proecdysis, in the moulting season removal of the eyestalk 
has no such effect and there is no evidence of the secretion of a moult-inhibiting hormone by the eyestalk. Moulting may, however, be inhibited during this period by some factor which emanates from some other centre than the eyestalk.

My thanks are due to my friend Dr P. F. R. Dohrn, of the Naples Zoological Station, in collaboration with whom I began investigations into the problem of moulting in Crustacea and who has been unfailing in his help and encouragement.

\section{SUMMARY}

During the moulting season in Carcinides maenas ablation of the eyestalks does not initiate proecdysis. Blood calcium levels, however, indicate that during this period moulting is partially inhibited by some factor emanating from some other centre than the eyestalk.

\section{REFERENCES}

BRoekhuysen, G. J., I936. On development, growth and distribution of Carcinides maenas (L.). Arch. néerl. Zool., Vol. 2, pp. 257-399.

Carlisle, D. B., I953. Moulting hormones in Leander (Crustacea Decapoda). F. Mar. biol. Ass. U.K., Vol. 32, pp. 289-95.

PASSANO, L. M., I953. Neurosecretory control of molting in crabs by the X organsinus gland complex. Physiol. comp., Vol. 3, I55-89.

Stephens, G. C., I95I. A molt-inhibiting factor in the central nervous system of the crayfish, Cambarus sp. Anat. Rec., Vol. III, pp. 572-3. 